\title{
Sublingual and subcutaneous allergen-specific immunotherapy as a method of treatment of patients with inhalant allergy - a review of the literature
}

\section{Podjęzykowa i podskórna immunoterapia swoistym alergenem jako metody leczenia pacjentów z alergią wziewna - przegląd piśmiennictwa}

\author{
Angelika Pawlak, Gabriela Ręka, Anna Korzeniowska, Halina Piecewicz-Szczęsna \\ Department of Epidemiology and Clinical Research Methodology, Medical University of Lublin, Lublin, Poland \\ Head of the Department: Agata Smoleń
}

Key words: allergy, allergic rhinitis, desensitisation, allergen immunotherapy.

Słowa kluczowe: alergia, alergiczny nieżyt nosa, odczulanie, immunoterapia alergenowa.

\begin{abstract}
Allergy is the result of the body's intolerance to harmless antigens. In the treatment of respiratory allergies, allergen immunotherapy (AIT) is a causal method of treating allergies. It can be carried out via the subcutaneous route (SCIT) or the sublingual route (SLIT) - in the form of drops or tablets. Desensitisation is recommended from the age of 5 years, and the doses of the drug should be repeated gradually so that the body acquires immunological tolerance to allergens. Thirty-six current publications from the PubMed and Google Scholar platforms were reviewed. A series of studies confirming the safety, efficacy, and good tolerability of both types of AIT in children and adults were referred to. The results presented in the review show the similarities and differences between the desensitisation methods. They differ, among other things, in the convenience of use, the price, the frequency of side effects of treatment, and the dosage.
\end{abstract}

\section{Streszczenie}

Alergia jest skutkiem nietolerancji organizmu na nieszkodliwe antygeny. Immunoterapia alergenowa (AIT) jest metodą przyczynowego leczenia alergii układu oddechowego. Można ją stosować drogą podskórną (SCIT) lub podjęzykową (SLIT) - w postaci kropli lub tabletek. Odczulanie zalecane jest od 5. roku życia, a dawki leku należy powtarzać stopniowo, aby organizm nabył tolerancję immunologiczną na alergeny. W artykule dokonano przeglądu 36 aktualnych publikacji z platform PubMed i Google Scholar. W pracy odniesiono się do licznych badań potwierdzających bezpieczeństwo, skuteczność i dobrą tolerancję obu rodzajów AIT u dzieci i dorosłych. Wyniki przedstawione w przeglądzie ukazują podobieństwa i różnice między metodami odczulania. Obie metody różnią się między innymi wygodą stosowania, ceną, częstością występowania skutków ubocznych leczenia oraz dawkowaniem.

\section{Introduction}

Allergy is caused by the body's intolerance to harmless antigens. Antigen-presenting cells (APCs) capture the allergen. Specific T helper 2 (Th2) and immunoglobulin E (IgE) cells are formed, which are characteristic of the allergen and are the main mediator of the allergic reaction. This causes disorders of the immune system, and the body overreacts to contact with the allergen [1]. The production of specific IgE antibodies is one of the 4 types of immunological mechanisms underlying allergies: 1) reaction mediated by IgE antibodies, which includes anaphylactic reactions; 2) cytotoxic reactions, which are mediated by proteins (IgG and IgM antibodies activating a com- ponent of immunity called the complement system); 3) immune-complex reactions, also mediated by IgM and IgG antibodies, reacting with the allergen to form antigen-antibody complexes; and 4) cell-mediated reactions (delayed type of hypersensitivity) mediated by the cellular response, which occur at least $24 \mathrm{~h}$ after exposure to the allergen [2]. Inhalant allergy is caused by pollen, animal hair, and house dust mites $[3,4]$. The most common reason for allergies is house dust mites (HDM). Moreover, allergic asthma is visibly associated with HDM sensitisation [5]. It is estimated that approximately $20-40 \%$ of the population in North America deal with rhinoconjunctivitis or allergic rhinitis and 8\% suffer from asthma [6]. 
Allergen immunotherapy (AIT) is used to treat respiratory allergies, which occur in patients with a frequency of 5-10\% according to other studies, and tend to increase [7, 8]. Immunotherapy as a causal treatment is reserved for immediate allergy - IgE-dependent allergy. The therapy is recommended from the age of 5 years due to difficulties in early diagnosis of the early symptoms of anaphylaxis [4]. The tasks of AIT include increasing the level of production of immunoglobulin G4 antibodies by increasing the number of Treg (regulatory T lymphocytes), interleukin 10 (IL-10), and B lymphocytes. It prevents the interaction of IgE with basophils and mast cells. Allergen immunotherapy inhibits the increase in the number of congenital type 2 lymphoid cells associated with the seasonal allergen. Moreover, AIT, by adaptive and innate immune mechanisms, reduces the infiltration of inflammatory cells in target tissues and inhibits allergen-specific Th2 cell responses [8]. In patients with inhalant IgE-mediated allergies, AIT is the only therapeutic option that modifies the course of illness $[9,10]$. AIT can be delivered via 2 different routes: the subcutaneous route (subcutaneous immunotherapy - SCIT) and the sublingual route (sublingual immunotherapy - SLIT). The doses of the drug should be repeated to gradually achieve immunological tolerance to allergens $[7,9,11]$. Allergen immunotherapy is recommended for the treatment of both perennial and seasonal allergies [3]. AIT reduces the patient's need for reliever allergy medications, improves patients' quality of life, and takes control of the symptoms of eye and nose allergies [10]. To obtain a long-lasting and significant effect, it is recommended to undergo at least a 3-year treatment cycle of the disease [3, 8, 9, 11-13]. It has been shown that with treatment lasting 3 to 5 years, symptom relief and improvements in the quality of life are sustained after cessation of treatment [14]. Other authors indicate that a 3-5 year disease treatment cycle is recommended in the elderly. After cessation of treatment, the effectiveness of the therapy is 7-12 years [8].

The purpose of the study is to review available data on oral and subcutaneous allergen immunotherapy with a comparison of both ways of administering the drugs. The latest available literature on the PubMed and Google Scholar databases was reviewed. The analysis concerned publications written as full-text in English between 2015 and 2020. The data were collected from the PubMed and Google Scholar databases using the following keywords: "inhalant allergy, desensitization, sublingual tablets, sublingual drops, subcutaneous method". Thirty-six papers were selected for analysis.

\section{Results}

\section{Sublingual allergen-specific immunotherapy}

Sublingual preparations (SLIT) are administered mainly in the form of tablets or liquid drop prepara- tions $[3,4,15]$. The advantage of using the sublingual route is the ability to take subsequent doses of the drug independently, without the need for a doctor's control. A difficulty for the patient may be the necessity to take the drug daily, which in practice may result in non-compliance with the recommendations regarding the regular taking of the drug [9]. Side effects of sublingual preparations include mild to moderate local oral allergic reactions such as throat irritation, ear itching, mucosal swelling, and oral itching $[3,7$, 15]. They can be reduced with oral antihistamines. If an ulcer or an open wound is healed in the mouth, the patient has had a tooth extraction or oral surgery, it is recommended to discontinue sublingual therapy for 7 days [3].

Sublingual formulations (SLIT) in tablet form are standardised, well-characterised formulations that, following evaluation in clinical trials, have been approved by regulatory agencies in the countries where they are marketed. Studies show that the effectiveness of sublingual tablets depends on the dose the patient is taking [7]. The first sublingual admission takes place under the supervision of an allergist doctor for $30 \mathrm{~min}[11,13]$. The tablet should be kept under the tongue for at least one minute and then swallowed [3]. The response to the first dose is very quick and aims to determine if it is well tolerated by the patient or not $[4,7]$. The use of sublingual tablets does not require increasing the dose during treatment. The initial effect on allergy symptoms begins after 4-8 weeks after initiation of treatment. Sublingual immunotherapy tablets aim to suppress allergy symptoms, to have a lasting clinical effect, and to maintain significant efficacy after treatment. The effectiveness of sublingual tablets has been proven in the case of allergic asthma in people of all ages and patients with multiple allergies, as well as in patients suffering from allergic rhinitis with or without conjunctivitis. Sublingual tablets are well tolerated. There is a very low risk of systemic allergic reactions [7].

Didier et al. conducted a randomised, double-blind, placebo-controlled study in 633 patients $18-50$ years of age with grass-pollen allergic rhinoconjunctivitis (ARC) lasting at least for the last 2 pollen seasons. The subjects also had a positive serum skin test of $\geq 0.7 \mathrm{kU} / 1$ for an extract of a mixture made of 5 grass pollens, as well as $\geq 12$ retrospective rhinoconjunctivitis total symptom score (RRTSS) on a $0-18$ scale during the most severe days in the grass pollen season. The aim of this multi-centre, parallel group, phase 3 study was to test the long-term efficacy of a 300 index of reactivity (IR) 5 -grass pollen tablet up to 5 years after the end of treatment. For 3 years, patients used either a placebo or sublingual tablet 300IR5 daily. They were monitored for the next 2 years, and they did not take the test product in these years. The study patients were randomly added to the 300IR 5 tablet 4 or 
2 months before the start of the grass pollen season until the end of its duration or to the placebo group. The obtained results showed that in patients taking 300IR5 sublingual tablets, effective long-term treatment of disease symptoms lasts up to 2 years after treatment. The results of this group of patients between the third and the fifth year of the study remained at a similar level, while the results of patients taking placebo in the years 3-5 continued to decline due to premature withdrawal of patients from the study [16].

In another randomised, double-blind, placebocontrolled study, Biedermann et al. studied 634 people 12-65 years of age suffering from moderate to severe ARC caused by tree pollen. The study was aimed at demonstrating the efficacy and safety of the SLIT sublingual tablet from the SQ tree. Eight percent of patients in the sublingual tablet group discontinued treatment due to an adverse event. Mild or moderate local reactions such as throat irritation and itching in the mouth were most commonly reported. There were no reports of anaphylaxis, airway obstruction, or patient death. Patients taking the sublingual tablet had an improvement in the mean daily ARC total score during the birch pollen season compared to placebo. The study proved that SQ tree sublingual tablets, compared to placebo, are safe and effective [17].

Okamoto et al. assessed the efficacy and safety of the 300IR HDM sublingual tablet in the treatment of allergic rhinoconjunctivitis caused by house dust mites. A total of 438 patients aged 5-16 years suffering from allergic rhinitis were enrolled in a double-blind, randomised, 52-week study. Immune responses in the tablet group were greater than in the placebo group. Mild to moderate side effects such as mouth swelling, ear itching, throat irritation, and mouth itching occurred in almost all patients. There were no anaphylaxis or deaths among the patients studied. The results showed that patients treated with the sublingual tablets showed a lower average adjusted symptom score (AASS), such as sneezing, nasal itching, nasal congestion, and rhinorrhoea compared to the placebo group. The effectiveness and safety of 300IR HDM tablets have been confirmed in a study [18].

In another randomised, double-blind, placebocontrolled study, Demoly et al. studied 992 moderately to severely allergic rhinitis patients aged 18 65 years. The study was designed to evaluate the safety and efficacy of the SQ HDM SLIT sublingual tablet. Patients were randomly divided into groups receiving 6 SQ-HDM, 12 SQ-HDM, or placebo. The results of the studies showed that in patients taking sublingual tablets there was a reduction in the symptoms of rhinitis and conjunctivitis, as well as an improvement in the quality of life compared to the group of patients taking placebo. Patients have reported mild local side effects of SLIT tablets such as mouth swelling, mouth itching, and throat irritation. One subject taking the 12 SQ-HDM tablets experienced mild laryngeal oedema requiring adrenaline. No systemic allergic reactions were reported in any of the groups tested. Thanks to the study, the authors proved the effectiveness and safety of SQ-HDM tablets in the studied age group [19].

Masuyama et al. in a randomised, double-blind, placebo-controlled study investigated the safety and efficacy of the SQ HDM SLIT sublingual tablet in 458 patients aged 5-17 years suffering from moderate to severe allergic rhinitis (AR). People taking the sublingual tablet had a significant reduction in rhinitis and conjunctivitis compared with placebo. Patients treated with SLIT tablets $(95.2 \%)$ reported mild to moderate side effects more often than those treated with placebo (87.9\%), while serious side effects were only seen in the placebo group. No anaphylaxis occurred in any of the study groups. The onset of asthma was reported in 2 patients in the placebo group and in 2 patients taking the tablets. The safety and effectiveness of SLIT tablets in the study group were confirmed [14].

Sublingual drops treatment can be self-administered at home; it begins with a shorter, gradual initiation phase, and the solution is typically kept under the tongue for 1-3 min before being swallowed [4, 20, 21]. By using SLIT drops, many allergens can be mixed, which increases the dosage variability of this drug [7]. Drops can be delivered via plastic single-use monodose squeeze vials, glass vials with droppers, metereddose pumps, or tuberculin syringes with the needle removed [22]. The stability of extracts is dependent on the diluent, temperature, and storage time. Exposure of standardized glycerin extracts (which are stable for up to 7 days at room temperature) to very high or freezing temperatures may decrease the potency or cause instability of some proteins. It is currently unknown if there are any differences in the mechanism of action between SLIT-T (SLIT tablets) and SLIT-D (SLIT drops). The limited data imply that important inequalities in the formulation affect absorption and dissolution, which is related to clinical efficacy and safety. There were no SLIT-D products approved by the Food and Drug Administration (FDA) in the United States in 2020; therefore, there is no standard dosing formula for this mode of administration [22].

A retrospective analysis of data from 2 prospective, randomised, placebo-controlled trials that involved 41 children, ages $6-18$ years, with allergic rhinitis (AR), and sensitivity to grass pollen was made by Jerzynska et al. The authors noticed that administration of both tablets and drops significantly reduced asthma, nasal, and ocular symptoms. Although the drop therapy was considered more effective in the reduction of combined symptom-medication score compared with the tablet therapy, the difference was not statistically significant $(p=0.1036)$ [23]. 
Zhong et al. evaluated sublingual immunotherapy with Dermatophagoides farinae drops in adult patients with allergic asthma (AA). The study included 134 patients (85 SLIT group and 49 control group) with HDM-induced AA, treated with long-acting $\beta 2$ agonists and low to moderate dose of inhaled glucocorticoid. Then patients in the SLIT group were treated with $D$. farinae drops (standardized HDM allergen extract). Significant reductions in total asthma symptom score (TASS) and total asthma medicine score (TAMS) for AA patients who received therapy of SLIT and pharmacotherapy after 1 - as well as 2 -year treatments $(p<0.001)$ were found. The TASS and TAMS in the SLIT group were both significantly lower than those in the control group $(p<0.01)$. Moreover, the asthma control test (ACT) score and peak expiratory flow rate $(\mathrm{PEF} \%)$ improvement were observed after 1 year of treatment in the SLIT and control group as well as between the 1-year treatment and the 2-year treatment only in the SLIT group (all $p<0.001$ ). In the study, the incidence of adverse events (AEs) (mild swelling or oral itching) in the SLIT group was higher than that in the control group (all relieved within a week, with or without therapy). The authors considered SLIT as more effective than pharmacotherapy in adult patients with HDM-induced AA [20].

Tang et al. conducted a retrospective study evaluating the safety and effectiveness of SLIT with $D$. farinae drops in pre-school and school-age children with allergic rhinitis. It included 282 patients between 2 and 13 years of age who received a 2-year course of SLIT along with pharmacotherapy. The 4 rhinitis symptom scores (sneezing, rhinorrhoea, nasal obstruction, itching), total nasal symptoms score (TNSS), total medication score (TMS), and visual analogue score (VAS) were significantly lower than baseline after 2-year SLIT (all $p<0.05$ ). It was found that subjective symptoms decreased significantly after 6 months of SLIT, and there were no significant differences between the 1- and 2-year therapy. Moreover, the efficacy persisted during the whole SLIT period. There were no reported severe systemic AEs, anaphylaxis, or use of adrenaline. Thirty patients reported 36 AEs, the majority of which were slight local reactions. SLIT with $D$. farinae drops is effective and safe in children with HDM-induced AR [21].

\section{Subcutaneous allergen-specific immunotherapy}

SCIT starts with weekly allergen injections, gradually increasing over 3-4 months, and then a phase with an injection every 4-6 weeks. The injection should be administered subcutaneously in the upper posterolateral arm. Due to the risk of anaphylactic shock, visits to the clinic are necessary during the administration of the drugs [4, 9]. A specific immunotherapy duration is not fully determined to obtain an optimal effect. Subcutaneous immunotherapy is usually administered constantly for at least 3 years. During the pollen season, the maintenance dose is lowered because of the risk of allergic systemic reactions [4]. After injection, the patient should stay on the premises for at least half an hour, due to the possibility of systemic reactions like anaphylactic shock. Adverse reactions mainly occur within $30 \mathrm{~min}$ after the injection. Serious anaphylactic reactions with the need for adrenaline were noted in approximately $3.5 \%$ of cases. Cough, dyspnea, rhinoconjunctivitis, asthma, and eczema are indicated as other systemic reactions. Local reactions are often well-tolerated and occur in SCIT in 26-86\% of injections. Among them, redness, pruritus, and swelling at the application site can be enumerated $[4,9]$.

In a double-blind, randomised, placebo-controlled trial, 554 adult patients with grass pollen rhinoconjunctivitis received in increasing doses in 4 visits over 3 weeks $170 \mu \mathrm{g}$ peptide hydrolysates from Lolium perenne (LPP) or 8 subcutaneous injections of placebo. Administration of $L$. perenne pollen peptides over 3 weeks before the grass pollen season notably diminished seasonal manifestation of allergy and was welltolerated and safe. The LPP-treated group had a lower reactivity to conjunctival provocation test and a lower rhinoconjunctivitis quality of life global score during the pollen season compared with the placebo group $(p<0.001$ and $p=0.005$, respectively). The average decrease in combined symptom and medication score in the LPP versus placebo group was $-15.5 \%$ during the peak season and $-17.9 \%$ over the entire pollen season ( $p=0.041$ and $p=0.029$, respectively) [24].

Huang et al. compared the efficacy of 3-year house dust mite subcutaneous immunotherapy in 124 paediatric and adult patients aged 5-51 years with allergic rhinitis. A total of 118 patients ( 44 children and 74 adults) were observed for 2 years after cessation of the treatment. Symptoms and quality of life scores were visibly improved at the end of the third and fifth years in children and adults in comparison with the baseline $(p<0.001)$. However, more sustained efficacy was seen among children compared to adults. The daily medication score was significantly reduced by the end of subcutaneous immunotherapy compared to the beginning of the treatment $(p<0.001)$. Among the group of 124 patients, 10 (8.1\%, 7 children and 3 adults) reported local adverse reactions and in 5 (4.2\%, 2 children and 3 adults) systemic adverse reactions, without the necessity of adrenaline, were observed. In 118 patients who finished a 2-year follow-up, local adverse effects were observed in $1(2.3 \%)$ child and $3(4.1 \%)$ adults. Three subjects presented with systemic side effects [25].

Effectiveness and safety of birch subcutaneous allergen immunotherapy were presented by Bożek et al. in a double-blind, placebo-controlled trial. Twentyeight patients with local allergic rhinitis were ran- 
domly assigned to 2 groups: 15 patients received immunotherapy and 13 patients received placebo. After 2 years of treatment, a significant decrease in the median area under the curve for symptom medication scores was noted (the active group vs. the placebo group: 2.14 vs. $6.21 ; p<0.05)$. The active group presented a decrease in symptom medication scores of up to $65 \%$ compared with the baseline. Systemic anaphylactic reactions were not observed in either group during the treatment. Between the active and placebo groups, there were comparable numbers of local adverse reactions; however, they were less frequent in the placebo group [26].

Rondón et al. conducted a randomised, doubleblind, placebo-controlled trial in which 36 patients with local allergic rhinitis due to $D$. pteronyssinus allergy received allergen immunotherapy or placebo for 24 months. In the research group versus placebo group significant improvements in symptoms, medication scores, medication-free days, skin tests, serumspecific IgE and IgG4, nasal allergen provocation test, and adverse events were observed. Immunotherapy was well-tolerated and no systemic adverse events were noted [27].

In another randomised, double-blind, placebocontrolled study Rondón et al. assessed 56 patients aged 18-55 years with moderate-severe local allergic rhinitis to Phleum pratense pollen. The patients in the first group $(n=26)$ received subcutaneous immunotherapy with a depigmented polymerised pollen vaccine for 2 years. In the second group $(n=29)$ they received placebo for the first year and SCIT for the next one. Significant improvements of all primary (combined symptom medication score) and secondary clinical outcomes (organ-specific symptoms, medication-free days, rhinitis severity, and asthma control) and Rhinoconjunctivitis Quality of Life Questionnaire score were noted. In the end, $83 \%$ of patients after at least 6 months of immunotherapy tolerated a concentration of allergen $>50$ times higher than at the baseline. The nasal allergen provocation test was negative in $56 \%$ of them. SCIT significantly elevated allergen tolerance and serum specific IgG4 levels from the $6^{\text {th }}$ to $24^{\text {th }}$ months of the administration. The method was well-tolerated, with no serious systemic adverse reactions and with 6 local mild reactions [28].

Bożek et al. evaluated the efficacy and safety of allergen-specific immunotherapy for house dust mite allergens in 58 elderly allergic rhinitis patients $(>65$ years old). In a double-blind, placebo-controlled trial patients were randomised into 2 groups: receiving perennial allergen-specific immunotherapy or placebo for 2 years. At the end of the study, the mean average adjusted symptom score significantly decreased in the active group from $4.27 \pm 1.58$ to $1.82 \pm 0.71$ $(p<0.05)$. The rhinoconjunctivitis quality of life questionnaire score improved in patients who were given immunotherapy from 1.82 (95\% CI: $1.54-1.92)$ to 1.26 (95\% CI: $1.09-1.55)$, whereas in the placebo group it was lower - continuously with the level of $1.74(95 \%$ CI: 1.27-1.86). Two mild systemic anaphylactic reactions were noted after injections of the drug [29].

\section{Comparison of both methods}

Sublingual allergen-specific immunotherapy (SLIT) and subcutaneous allergen-specific immunotherapy (SCIT) with tablets and with drops are both highly effective in allergic diseases according to different research $[4,30]$. However, SCIT is usually considered as more effective and with faster onset [30]. In research after 2 years of allergic immunotherapy with house dust mite extract for patients with allergic rhinitis, there was no significant difference in the diminution of the total nasal symptoms between the SCIT and SLIT groups. VAS score of nasal obstruction was significantly reduced in the SCIT group versus SLIT group [30].

Sublingual ways of administration are easier and have less anaphylactic risk [4]. With the sublingual method (SLIT), the doses usually need to be administered daily, by the recipient, at home. With the subcutaneous method (SCIT), doses are given every 1 or 2 weeks, or monthly under the supervision of a doctor in a clinic or hospital [15]. SLIT is considered safer than SCIT because no fatalities have been reported and the number of severe systemic reaction events is very low. The most common adverse effects of SLIT are mild local application site reactions, such as oral pruritus and throat irritation, which in the case of SLIT-T resolve within 30 to $60 \mathrm{~min}$ and decrease over time [22, 30]. After administration of a sublingual tablet, anaphylactic shock occurs once every 100 million administrations, while after subcutaneous injection the incidence of anaphylaxis increases to one in 33,300 injections [7, 15].

The indications for the treatment of allergies with SLIT include immunological indications and clinical indications. Immune indications include IgE-mediated hypersensitivity to house dust mites, pollen, or cat fur, and evidence of clinical relevance of hypersensitivity - immunisation. However, clinical indications include the appearance of significant symptoms of the disease as a result of contact with the above-mentioned allergens and the occurrence of such disease entities as controlled atopic asthma, characterised by mild to moderate course, allergic rhinitis, and conjunctivitis [31]. Similar indications apply to subcutaneous immunotherapy. In this respect, both methods of allergen immunotherapy are similar to each other [32]. The decision between SLIT or SLIT depends on several factors including, for example, product availability, cost, patients' ability to consistently attend the clinic, as well as physician's or patient's preference. It 
is worth noting that SLIT could be tried if SCIT causes systemic reactions [33].

Contraindications to the introduction of allergen immunotherapy in patients include pregnancy, active systemic autoimmune disorders, uncontrolled asthma, and active malignant neoplasia. Caution is advised in the use of AIT when the benefits of treatment outweigh the risks of associated side effects. Such cases include partially controlled asthma, $\beta$-blocker therapy, severe cardiovascular disease, primary and secondary immunodeficiencies, severe psychiatric, organ-specific, or remitted systemic autoimmune disorders, and a history of serious systemic reactions to allergen immunotherapy [3]. SLIT and SCIT present similar relative and absolute contraindications. For example, non-controlled asthma and treatment-resistant, active autoimmune diseases are absolute contraindications, whereas cardiovascular diseases and chronic infections are relative contraindications.

Four meta-analyses were conducted, which all found that SLIT-T had a greater effect than SLIT-D considering symptom treatment effect. In 2 of the comparisons, SLIT-T had a larger effect than SLIT-D, regarding medication use treatment effect, and in 1 study SLIT-D had the larger treatment effect. The medication use treatment effects were similar in the fourth comparison. However, it is not known whether the differences could arise from the dose [22].

Rodríguez Del Río et al. assessed the adverse systemic reactions in allergen immunotherapy among European children. The study included a total of 1563 participants (762 children and 801 adolescents). $71.4 \%(n=1127)$ of patients received SCIT and $28.6 \%$ $(n=451)$ received SLIT (drops: $n=333,73.8 \%$; tablets: $n=118,26.2 \%)$. There were 29 reported systemic reactions (SRs) in 24 patients; 23 (79.3\%) of them were caused by SCIT (21 (91.3\%) were related to natural extracts) and $6(20.7 \%)$ were caused by SLIT (5 (83.3\%) with drops and 1 (17.7\%) with tablets). Most of the SRs were classified as mild (72.4\%), one of them was severe. Moreover, there were 3 (10.3\%) anaphylactic reactions (all related to SCIT). Most of the SLITassociated SRs $(66.6 \%)$ resolved without anti-allergic medication. Predominantly SRs occurred more than $24 \mathrm{~h}$ after AIT administration (37.9\%), then $27.6 \%$ SRs occurred in the first $30 \mathrm{~min}$ as well as from $2 \mathrm{~h}$ to $24 \mathrm{~h}$ afterward and $6.9 \%$ from 30 min to $2 \mathrm{~h}$ afterward. The severity of SRs was not related to the time of onset of symptoms. AIT is a safe treatment among the paediatric population and is associated with the occurrence of a low incidence of generally mild SRs [34].

Although both SCIT and SLIT are safe and effective treatments of inhalant allergies, the choice of administration of AIT varies from country to country and depends on clinical data, availability, price, or patient preferences. SLIT by tablets was cheaper than SCIT over a 3-year period of treatment in a Danish study of house dust mite-related allergic rhinitis [4]. Polish patients can purchase only SCIT preparations in a refund. None of the SLIT preparations are refundable, which makes this therapy more expensive and hence less frequently used. Taking the tablet daily (SLIT) may not be a good method for patients who will not remember to take it regularly. However, the lack of possibility of a patient travelling to the clinic for SCIT administration might be a drawback in this type of AIT.

The guidelines of Polish Society of Allergology state that immunotherapy should be continued for at least 3 years, for both SCIT and SLIT. If the effects are very good after 3 years, the immunotherapy should be terminated. If they are good but the allergen tolerance has not been achieved satisfactorily, it should be continued for up to 5 years. The time of initiation of immunotherapy varies depending on the type of allergy - to seasonal or all-year-round allergies. In the case of seasonal allergy, the beginning of allergen immunotherapy should begin before the beginning of the natural exposure season. Starting AIT is possible all year for year-round allergies. For subcutaneous immunotherapy, the treatment initiation period is $4-13$ weeks or 24 weeks before the pollen season begins. Sublingual immunotherapy can be initiated either pre-season or per season. The start of pre-season treatment is 16 weeks before the pollen season starts and ends just before the season starts. Treatment for per season immunotherapy begins at least 8 or 16 weeks before the pollen season begins and continues for a further 8 weeks during that season. It is recommended to start the treatment 4 months before the pollen season and continue it until the end of this season. All-year immunotherapy with both SCIT and SLIT should be carried out year-round - for SCIT every 4-6 weeks and for SLIT every day or every 2 days, depending on the preparation used [35]. Before a decision is made on the use of allergen immunotherapy and possible changes in the pharmacotherapy of comorbidities, the benefits, and risks of a specific treatment should be assessed first. Coexisting diseases may constitute a contraindication to the use of allergen immunotherapy. If there is a possibility of changing a drug potentially contributing to an increase in the risk of an adverse reaction resulting from the use of AIT, it should be changed even though it does not have a significant effect on the development of the comorbid condition [36].

\section{Conclusions}

Sublingual and subcutaneous allergen-specific immunotherapy are effective, safe, and well-tolerated methods of treatment of inhalant allergy, according to recent studies, both in children and in adults. Some studies indicate that SCIT has a greater immunologic response. Both methods require high patient adherence to be fully effective. SLIT is considered to be 
an easier way of getting the drug into the body and a method with a lower risk of anaphylactic reaction compared to the subcutaneous administration. In the case of sublingual methods, the lack of injection and a favourable safety profile make the use of sublingual preparations the preferred method of desensitisation in children. Both methods are marked by similar contraindications although some differences are enumerated. Sublingual preparations should not be administered in the case of tooth extraction or if there are any lesions of the oral mucosa. The subcutaneous method should not be used in patients with an increased risk of systemic complications during immunotherapy. The refund of SLIT therapy could contribute to its more frequent use in Poland, which would be beneficial especially in the current SARS-CoV-2 pandemic, reducing the number of visits to the doctors. Further research on the dosage of sublingual drops is needed as well as on the possibility of combining allergens in one dose.

\section{Conflict of interest}

The authors declare no conflict of interest.

\section{References}

1. Bacher P, Scheffold A. Antigen-specific regulatory T-cell responses against aeroantigens and their role in allergy. Mucosal Immunol 2018; 11: 1537-1550.

2. Marwa K, Kondamudi NP. Type IV hypersensitivity reaction. In: StatPearls. Treasure Island (FL): StatPearls Publishing; March 7, 2021.

3. Roberts G, Pfaar O, Akdis CA, Ansotegui IJ, Durham SR, Gerth van Wijk R, Halken S, Larenas-Linnemann D, Pawankar R, Pitsios C, Sheikh A, Worm M, Arasi S, Calderon MA, Cingi C, Dhami S, Fauquert JL, Hamelmann E, Hellings P, Jacobsen L, Knol EF, Lin SY, Maggina P, Mösges R, Oude Elberink JNG, Pajno GB, Pastorello EA, Penagos M, Rotiroti G, Schmidt-Weber CB, Timmermans F, Tsilochristou O, Varga EM, Wilkinson JN, Williams A, Zhang L, Agache I, Angier E, Fernandez-Rivas M, Jutel M, Lau S, van Ree R, Ryan D, Sturm GJ, Muraro A. EAACI Guidelines on allergen immunotherapy: allergic rhinoconjunctivitis. Allergy 2018; 73: 765-798.

4. Mortuaire G, Michel J, Papon JF, Malard O, Ebbo D, Crampette L, Jankowski R, Coste A, Serrano E. Specific immunotherapy in allergic rhinitis. Eur Ann Otorhinolaryngol Head Neck Dis 2017; 134: 253-258.

5. Gunawardana NC, Zhao Q Carayannopoulos LN, Tsai K, Malkov VA, Selverian D, Clarke G, Mant T, Butts BD, Lund K, Hansel TT, Nolte H. The effects of house dust mite sublingual immunotherapy tablet on immunologic biomarkers and nasal allergen challenge symptoms. J Allergy Clin Immunol 2018; 141: 785-788.

6. Creticos PS. Allergen immunotherapy: vaccine modification. Immunol Allergy Clin North Am 2016; 36: 103-124.

7. Nolte $\mathrm{H}$, Maloney J. The global development and clinical efficacy of sublingual tablet immunotherapy for allergic diseases. Allergol Int 2018; 67: 301-308.

8. Hur GY, Lee JH, Park HS. Allergen immunotherapy for the treatment of respiratory allergies in the elderly. Curr Opin Allergy Clin Immunol 2017; 17: 304-308.
9. Pfaar O, Lou H, Zhang Y, Klimek L, Zhang L. Recent developments and highlights in allergen immunotherapy. Allergy 2018; 73: 2274-2289.

10. Eguiluz-Gracia I, Ariza A, Testera-Montes A, Rondón C, Campo P. Allergen immunotherapy for local respiratory allergy. Curr Allergy Asthma Rep 2020; 20: 23.

11. Klimek L, Mosbech H, Zieglmayer P, Rehm D, Stage BS, Demoly P. SQ house dust mite (HDM) SLIT-tablet provides clinical improvement in HDM-induced allergic rhinitis. Expert Rev Clin Immunol 2016; 12: 369-377.

12. Penagos M, Durham SR. Duration of allergen immunotherapy for inhalant allergy. Curr Opin Allergy Clin Immunol 2019; 19: 594-605.

13. Muraro A, Roberts G, Halken S, Agache I, Angier E, Fernandez-Rivas $M$, Gerth van Wijk R, Jutel M, Lau S, Pajno G, Pfaar O, Ryan D, Sturm GJ, van Ree R, Varga EM, Bachert C, Calderon M, Canonica GW, Durham SR, Malling HJ, Wahn U, Sheikh A. EAACI guidelines on allergen immunotherapy: executive statement. Allergy 2018; 73: 739-743.

14. Masuyama K, Okamoto Y, Okamiya K, Azuma R, Fujinami T, Riis B, Ohashi-Doi K, Natsui K, Imai T, Okubo K. Efficacy and safety of SQ house dust mite sublingual immunotherapy-tablet in Japanese children. Allergy 2018; 73: 2352-2363.

15. Brunton S, Nelson HS, Bernstein DI, Lawton S, Lu S, Nolte H. Sublingual immunotherapy tablets as a diseasemodifying add-on treatment option to pharmacotherapy for allergic rhinitis and asthma. Postgrad Med 2017; 129: 581-589.

16. Didier A, Malling HJ, Worm M, Horak F, Sussman GL. Prolonged efficacy of the 300IR 5-grass pollen tablet up to 2 years after treatment cessation, as measured by a recommended daily combined score. Clin Transl Allergy 2015; 5: 12 .

17. Biedermann T, Kuna P, Panzner P, Valovirta E, Andersson M, de Blay F, Thrane D, Jacobsen SH, Stage BS, Winther L. The SQ tree SLIT-tablet is highly effective and well tolerated: results from a randomized, double-blind, placebo-controlled phase III trial. J Allergy Clin Immunol 2019; 143: 1058-1066.

18. Okamoto Y, Fujieda S, Okano M, Hida H, Kakudo S, Masuyama K. Efficacy of house dust mite sublingual tablet in the treatment of allergic rhinoconjunctivitis: a randomized trial in a pediatric population. Pediatr Allergy Immunol 2019; 30: 66-73.

19. Demoly P, Emminger W, Rehm D, Backer V, Tommerup L, Kleine-Tebbe J. Effective treatment of house dust mite-induced allergic rhinitis with 2 doses of the SQ HDM SLITtablet: results from a randomized, double-blind, placebocontrolled phase III trial. J Allergy Clin Immunol 2016; 137: 444-451.

20. Zhong C, Yang W, Li Y, Zou L, Deng Z, Liu M, Huang X. Clinical evaluation for sublingual immunotherapy with Dermatophagoides farinae drops in adult patients with allergic asthma. Ir J Med Sci 2018; 187: 441-446.

21. Tang LX, Yang XJ, Wang PP, Ge WT, Zhang J, Guo YL, Lu J, Tai J, Zhang YM, Ni X. Efficacy and safety of sublingual immunotherapy with Dermatophagoides farinae drops in pre-school and school-age children with allergic rhinitis. Allergol Immunopathol 2018; 46: 107-111.

22. Tankersley M, Han JK, Nolte H. Clinical aspects of sublingual immunotherapy tablets and drops. Ann Allergy Asthma Immunol 2020; 124: 573-582. 
23. Jerzynska J, Stelmach W, Majak P, Stelmach R, Janas A Stelmach I. Comparison of the effect of 5-grass pollen sublingual immunotherapy tablets and drops in children with rhinoconjunctivitis. Allergy Asthma Proc 2018; 39: 66-73.

24. Mösges R, Bachert C, Panzner P, Calderon MA, Haazen L, Pirotton S, Wathelet N, Durham SR, Bonny MA, Legon T, von Frenckell R, Pfaar O, Shamji MH. Short course of grass allergen peptides immunotherapy over 3 weeks reduces seasonal symptoms in allergic rhinoconjunctivitis with/without asthma: a randomized, multicenter, double-blind, placebo-controlled trial. Allergy 2018; 73: 1842-1850.

25. Huang Y, Wang C, Cao F, Zhao Y, Lou H, Zhang L. Comparison of long-term efficacy of subcutaneous immunotherapy in pediatric and adult patients with allergic rhinitis. Allergy Asthma Immunol Res 2019; 11: 68-78.

26. Bożek A, Kołodziejczyk K, Jarząb J. Efficacy and safety of birch pollen immunotherapy for local allergic rhinitis. Ann Allergy Asthma Immunol 2018; 120: 53-58.

27. Rondón C, Campo P, Salas M, Aranda A, Molina A, González M, Galindo L, Mayorga C, Torres MJ, Blanca M. Efficacy and safety of D. pteronyssinus immunotherapy in local allergic rhinitis: a double-blind placebo-controlled clinical trial. Allergy 2016; 71 1057-1061.

28. Rondón C, Blanca-López N, Campo P, Mayorga C, JuradoEscobar R, Torres MJ, Canto G, Blanca M. Specific immunotherapy in local allergic rhinitis: a randomized, double-blind placebo-controlled trial with Phleum pratense subcutaneous allergen immunotherapy. Allergy 2018; 73: 905-915.

29. Bożek A, Kołodziejczyk K, Kozłowska R, Canonica GW. Evidence of the efficacy and safety of house dust mite subcutaneous immunotherapy in elderly allergic rhinitis patients: a randomized, double-blind placebo-controlled trial. Clin Transl Allergy 2017; 7: 43.

30. Guan K, Liu B, Wang M, Li Z, Chang C, Cui L, Wang RQ Wen LP, Leung PSC, Wei JF, Sun JL. Principles of allergen immunotherapy and its clinical application in China: contrasts and comparisons with the USA. Clin Rev Allergy Immunol 2019; 57: 128-143.

31. Jutel M, Bartkowiak-Emeryk M, Bręborowicz A, CichockaJarosz E, Emeryk A, Gawlik R, Gonerko P, Rogala B, Nowak-Węgrzyn A, Samoliński B; IT Section, PTA. Sublingual immunotherapy (SLIT) - indications, mechanism, and efficacy: position paper prepared by the Section of Immunotherapy, Polish Society of Allergy. Ann Agric Environ Med 2016; 23: 44-53.

32. Kowalski ML. Wskazania do immunoterapii alergenowej - algorytm kwalifikacji. Pol J Allergol 2018; 5: 129-132.

33. Tsabouri S, Mavroudi A, Feketea G, Guibas GV. Subcutaneous and sublingual immunotherapy in allergic asthma in children. Front Pediatr 2017; 5: 82

34. Rodríguez Del Río P, Vidal C, Just J, Tabar AI, SanchezMachin I, Eberle P, Borja J, Bubel P, Pfaar O, Demoly P, Calderón MA. The European survey on adverse systemic reactions in allergen immunotherapy (EASSI): a paediatric assessment. Pediatr Allergy Immunol 2017; 28: 60-70.

35. Gocki J, Bartuzi Z. Wytyczne/zalecenia. Podskórna i podjęzykowa droga stosowania immunoterapii alergenowej. Schematy leczenia. Pol J Allergol 2018; 5: 137-144.

36. Kowal J. Strategia leczenia chorób współistniejących a decyzja o immunoterapii alergenowej. Pol J Allergol 2018; 5: $157-162$.

\section{Address for correspondence:}

\section{Angelika Pawlak}

Department of Epidemiology and

Clinical Research Methodology

Medical University of Lublin

Lublin, Poland

E-mail: angelika.pawlak5@wp.pl 